\title{
Influence of Nitrogen Fertilizer Rates and Varieties on Growth, Grain Yield and Yield Components of Tef [Eragrostis tef (Zucc.) Trotter]
}

\begin{abstract}
A field experiment was conducted to assess the influence of $\mathrm{N}$ fertilizer rates on growth, grain yield and yield components of Tef [Eragrostis tef (Zucc.) Trotter], in 2017 main cropping season. Three tef varieties (Kora, Boset and Asgori) and five Nitrogen rates $\left(0,30,60,90\right.$ and $\left.120 \mathrm{~kg} \mathrm{~N}^{-1}\right)$ were used in Randomize Completed Block Design with three replications with the same dose of Triple Super Phosphate. The total and productive tiller number were highly $(\mathrm{P}<0.01)$ significantly affected by varieties. The control plot had maximum days to heading and this may be due to nitrogen fixation may exist and its availability may be deficient in the soil. The less response to the $\mathrm{N}$ rate may be due to variability of fertility or soil $\mathrm{N}$ content, and genetically difference between varieties. From means of varieties, the early flowerings of Boset and Asgori varieties were 101.4 and 103.79 days to maturity, respectively, but Kora (108.9 days) was late matured. Kora had maximum plant height $(135.9 \mathrm{~cm})$ and panicle length $(56.07 \mathrm{~cm})$ followed by Boset $(115.1 \mathrm{~cm})$ and $(42.49 \mathrm{~cm})$ respectively. The lodging index was affected by $\mathrm{N}$ rates and Kernel weight was highly significantly $(\mathrm{P}<0.01)$ affected only by varieties. The highest mean of thousand kernel weight (0.3387) was noted from Asgori variety. The grain yield was decreased with $\mathrm{N}$ rates and a better grain yield was obtained at $60-90 \mathrm{~kg} \mathrm{~N} \mathrm{ha}^{-1}$. Overall $\mathrm{N}$ rates indicated that, both Kora (1800) and Boset (1883) had a better grain yield in $\mathrm{kg}$ ha1 , but Asgori had lowest grain yield $\left(1560 \mathrm{~kg} \mathrm{ha}^{-1}\right)$. Based on the economic point of view, it would be more profitable to use $60 \mathrm{~kg} \mathrm{~N}$ ha $^{-1} \mathrm{~N}$ rates.
\end{abstract}

Keywords: tef varieties, Nitrogen, fertilizer rates, phenological growth and yield components
Volume 5 Issue 5 - 2020

\author{
Hayelom Berhe, ' Ashagrie Zewdu, ${ }^{2}$ Kbebew \\ Assefa $^{3}$ \\ 'Food Science and Nutrition, Ethiopia Institute of Agricultural \\ Research, Ethiopia \\ ${ }^{2}$ Center for Food Science and Nutrition, Addis Ababa University, \\ Ethiopia \\ ${ }^{3}$ Plant Breeding and Genetics, Ethiopian Institute of Agricultural \\ Research, Ethiopia
}

Correspondence: Hayelom Berhe, Food Science and Nutrition, Ethiopian Institute of Agricultural Research, PO Box 2003, Addis Ababa, Ethiopia, Tel +25 19-25-74-30-05, Email berhehayelom 18@gmail.com

Received: August 17, 2020 | Published: September 30, 2020
Abbreviations: P, Phosphorus; N, Nitrogen; DZARC, debere ziet agricultural research center; MARC, melkassa agricultural research center; EIAR, Ethiopian institute of agricultural research; t, tonne; ha, hectare; RCBD, randomized complete block design; $0,30,60,90,120$, Nitrogen fertilizer rates $\mathrm{kg}$ per hectare, $\mathrm{cm}$, centimeter; SE, standard error; EC, electrical conductivity; $\mathrm{pH}$, power of hydrogen; ds, des semen; OC, organic carbon; OM, organic matter; TN, total nitrogen; Ava.P, Available Phosphorus; CV, coefficient of variation; $\mathrm{kg}$, kilogram; $\mathrm{HI}$, harvest index; $\mathrm{K}$, kora tef variety; $\mathrm{B}$, boset tef variety; $\mathrm{A}$, asgori tef variety; $\mathrm{K} 0, \mathrm{~B} 0$, and $\mathrm{A} 0$, kora, boset and asgori with zero nitrogen fertilizer rates; K30, B30, A30, kora, boset and asgori with $30 \mathrm{~N}$ rates; K60, B60, A60, kora, boset and asgori with $60 \mathrm{~N}$ rates; K90, B90, A90, kora, boset and asgori with 90kg N ha $^{-1}$ rates; K120, B120, A120, kora, boset and asgori with $120 \mathrm{~N}$ rates; GMK, grand mean of kora; GMB, grand mean of boset; GMA, grand mean of asgori; AGDB, above ground dry biomass; GY, grain yield

\section{Introduction}

Tef (Eragrostis tef (Zucc) Trotter) is Ethiopia's Miracle crop. It is an annual grass species and a member of the grass family poaceae and genus Eragrostis. ${ }^{1}$ Tef is a small-grained cereal crop that has been grown as food crop in East Africa for thousands of years. ${ }^{2}$ Tef is a panicle bearing C4 self-pollinated annual cereal crop. ${ }^{1}$ Tef is an allotetraploid plant with a chromosome number of $2 n=40$ and the basic chromosome number of the genus Eragrostis is $X=10 .{ }^{3}$ Because of highly diversified agro-ecological systems, Ethiopia is the origin and genetic diversity for many crops that are economically important. ${ }^{4,5}$ Tef has been introduced to different parts of the world through various institutions and individuals. The Royal Botanic Gardens, Kew, imported seed from Ethiopia in 1866 and distributed it to India, Australia, the USA and South Africa.

Tef has the largest share of area (million hectares) or $29 \%$ of, under cereal cultivation and third (after maize and wheat) in terms of grain production (18.57\% or 50.2 million quintals) in Ethiopia. ${ }^{6}$ According to Central Stastical Agency (CSA), ${ }^{7}$ in Ethiopia the total tef cultivated area in the main rainy season of the 2010/2011 was 2,761,190 ha. Tef withstands low moisture conditions and has the ability to tolerate and grow on Vertisol having a drainage problem, which makes it a preferred by farmers. Compared with other cereal crops, tef has the ability to show a good performance on water lodged vertisoils in the highlands and with moisture stress areas in the semi-aired regions in the country. ${ }^{8}$ Balesh ${ }^{9}$ reported that due to the lack of adequate synthetic fertilizer input, the limited return of organic residue and manure, high biomass removal, erosion and leaching of high rate nutrient depletion in soil. Soil degradation and depletion of soil nutrients are among the major factors intimidating sustainable cereal production in the Ethiopian highlands. Among the major plant nutrients, $\mathrm{N}$ is the most limiting factor calling for external inputs in the form of fertilizer for commercial cereal crop production in most agro-ecological zones. As cited by Giday, ${ }^{10}$ who reported that nitrogen fertilizers have easily solubilizing properties, thus the fertilizer applied to the soil can be lost from the soil-plant system and this makes the nutrient inaccessible for the plants through different mechanisms and the recovery of $\mathrm{N}$ by the crops from the soluble $\mathrm{N}$ fertilizer such as urea is often as low as $30-40 \% .^{11}$ 
Cereal crops such as Maize have different responses for chemical fertilizer applications especially for Nitrogen and Phosphorus in different agroecological zones. ${ }^{12}$ Ethiopian soil productivity reduction is associated with loss of the soil organic matter. ${ }^{13} \mathrm{~A}$ soil organic amendment plays a significant role in nutrient availability and nutrient recycling by releasing the nutrients into the soil and this inducing mineralization mobility. On the other hand, the integrated applications of organic and mineral fertilizer which are the best ways of soil fertility management can improve crop yield productions and soil fertility status. ${ }^{14}$ The major form of nitrogen fertilizer used is urea, is efficient, very soluble and moves freely up and down with soil moisture. ${ }^{15}$ Many farmers are unable to compensate for such losses, which resulted in negative nutrient balances. ${ }^{16}$ Nitrogen in the soil can be exists in different forms and in large amount, and it may exist beyond the demand of some crops. Even though all forms $\mathrm{N}$ are not available to plants, it is found in the form of organic matter more than $90 \% .^{17}$

As compared with other cereal crops such as wheat and sorghum, the production of tef is very low. This is because of many yield-limiting factors of which poor soil fertility and low soil moisture are typical in the semi-arid parts of the country. Since tef is valuable to the Ethiopian economy in terms of supplying grain for human consumption and fodder for livestock, it is crucial to address the fertility constraints so as to increase its production. Among the essential nutrients, both nitrogen and phosphorous are required in large quantities for optimum growth and yield of crop plants. Since Organic-P has lower $\mathrm{N}$ concentration $(1 \%)$ in relation to other nutrients, therefore, there is a need to find out the right nitrogen fertilizer rates at the same doses of Organic-P for optimum yields of tef. The hypothesis of this experiment is that different $\mathrm{N}$ fertilizer rates with the same dose of Organic-P will improve the growth and yield component of tef. Our objective therefore, was to assess the influence of $\mathrm{N}$ fertilizer rates and varieties on grain yield and yield components and the optimum levels of $\mathrm{N}$ fertilizers for tef yield on Vertisol.

\section{Material and methods \\ Description of the study site}

The field study was carried out at Debre Zeit Agricultural Research Center (DZARC) from August - November during the main cropping season of 2017. Debre Zeit is located at $47 \mathrm{~km}$ to the southeast of Addis Ababa. The experimental field at this site is characterized by heavy black soil which is the dominant soil of the study area with high water retention capacity by its nature. The place is located at $8^{\circ} 44^{\prime} \mathrm{N}$ latitude and $38^{\circ} 58^{\prime} \mathrm{E}$ longitude at an altitude of 1860 meters above sea level. The study area receives an annual average rainfall of about 832, and the average minimum and maximum mean temperatures are about 8.9 and $24.3^{\circ} \mathrm{c}$ respectively.

\section{Plant materials}

The field experimental materials were three tef varieties having a different color and yield production potential through different ecological zones. These tef varieties were released and breed by DZARC in different years with different agronomical parameters (Table 1). The basic criteria for the selections of these three tef varieties were that Kora was recently genetically developed tef variety, while Boset tef variety is due to its early maturity and Asgori tef variety is because of its brown seeded color.

Table I Descriptions of plant materials

\begin{tabular}{llllllll}
\hline No & Tef varieties & $\begin{array}{l}\text { Local } \\
\text { name }\end{array}$ & Seed color & $\begin{array}{l}\text { Year of } \\
\text { release }\end{array}$ & $\begin{array}{l}\text { Days to } \\
\text { maturity }\end{array}$ & \multicolumn{2}{c}{ Yield (t/ha) } \\
\hline I & DZ-Cr-438RILI33B & Kora & Very white & 2014 & $110-117$ & $2.5-2.8$ & $2.0-2.2$ \\
2 & DZ-Cr-409 RIL50d & Boset & Very white & 2012 & $75-86$ & $1.8-2.0$ & $1.4-1.8$ \\
3 & DZ-01-99 & Asgori & Brown & 1970 & $80-130$ & $2.2-2.8$ & $1.8-2.2$
\end{tabular}

Source: Personal communication and from Recording data of Debere Ziet Agricultural Research Center (DZARC).

\section{Experimental treatments and designs}

The experiment was comprised of the entire factorial combinations of three tef varieties (two white seeded ones of Kora and Boset and one brown seeded Asgori) and five nitrogen fertilizer rates (0, 30, 60, 90 and $120 \mathrm{~kg} \mathrm{~N} \mathrm{ha}^{-1}$ ). The factorial combination was laid in Randomized Complete Block Design (RCBD) with three replications.

\section{Experimental management}

The field experiment was conducted at DZARC experimental research site in the main cropping season. The land was prepared according to the recommended practice in the research center. It was plowed two times using a tractor before sowing and the last ploughing was used for sowing seeds. The total area of the experimental field was $47 \mathrm{~m} \times 37 \mathrm{~m}$ which is equal to $1739 \mathrm{~m}^{2}$. The plot size was $5 \mathrm{~m} \mathrm{x}$ $5 \mathrm{~m}=25 \mathrm{~m}^{2}$. The distance between plots and blocks were 1 and $1.5 \mathrm{~m}$, respectively.

\section{Data Collection}

\section{Soil physico-chemical analysis}

The composite soil sample was collected by using a randomized zigzag method before sowing using $0-15 \mathrm{~cm}$ soil depth. A total of 45 soil sample was collected from the entire experimental field. The sample was packed using polyethylene bags and transported to the laboratory. Then the soil sample was dried in a shaded area from direct sunlight. The dried soil samples were grounded using soil grinder machine which increases the surface area of the soil and this was passed through $0.5 \mathrm{~mm}$ mesh sieve size. Soil $\mathrm{pH}$ was determined using a glass electrode attached to a digital $\mathrm{pH}$ meter (potentiometer). Electrical conductivity was measured using a conductivity meter. Organic carbon and total nitrogen were determined using the method of Walkely and Black. ${ }^{18}$ and Kjeldhal methods, respectively. ${ }^{19}$ Available phosphorus of the soil sample was determined using the Olsen method. ${ }^{20}$ 


\section{Phenology and growth parameters}

Plant parameters; phenology and growth parameters (heading days, maturity date, plant height, panicle length, total and number of productive tillers per plant) were determined according to the recommended practice. Panicle length was measured by pre-tagging ten randomly plants from the middle parts of each plot and measured from the nods (the first panicle branch stared) to the tip of the panicle. The maturity date was assessed based on visual observation as indicated by the senescence of the leaves and free threshing of grains from the glumes when pressed between the forefinger and thumb. Plant height was measured at physiological maturity from the ground to the tips of panicle using ten randomly pre-tagged plants in each plot. Panicle length was measured by pre-tagging ten randomly plants from the middle parts of each plot and measured from the nods (the first panicle branch stared) to the tip of the panicle. The numbers of the total tillers per plant were determined by counting all the tillers from randomly selected and ten pre-tagged plants from the center of each plot. On the other hand, the numbers of productive tillers per plant were measured by counting the fertile tillers from ten randomly selected and pre-tagged plants from the middle parts of each plot.

\section{Yield and yield components}

Yield and yield components (lodging index, above-ground dry biomass, grain yield, straw yield, harvest index and thousand kernel weight) were determined following standard methods. Lodging index was computed as the average of the product sum of each degree of lodging $(0-5$ scale) and their respective percentage of the total area divided by five. It was recorded by using Caldicott and Nuttall ${ }^{21}$ method. Above ground biomass yield was determined at maturity by weighing the whole plants (leaves, stems, chaff and kernels) harvested from the net plot area after sun drying using balance. The grain yields were measured by harvesting the grains crop harvested from the net plot area of $5 \mathrm{mx} 5 \mathrm{~m}\left(25 \mathrm{~m}^{2}\right)$ excluding the border effects using balance.
After threshing and measuring the grain yield; the straw yield was determined by subtracting the grain yield from the total above ground biomass yield. The mass thousand seed were determined for each plot by carefully counting the grains individually and weighing them using a sensitive balance. The harvest index was calculated by dividing the grain yield by the total above ground air dry biomass yield and multiplying by 100 to get it as percentage described in the equation below. The mass thousand seed were determined for each plot by carefully counting the grains individually and weighing them using a sensitive balance.

\section{Statistical analyses}

All agronomical measurements were measured in triplicate and the results were recorded as mean \pm standard error (SE). The variation between the mean levels in all treatments was measured using GenStat $17^{\text {th }}$ edition www.vsni.co.uk software. Multiple comparisons between factor levels were done. GenStat $17^{\text {th }}$ edition is widely used statistical software to check the presence of significant difference at 95\% confidence level between mean levels in each treatment.

\section{Results and discussion}

\section{Soil physicochemical properties of the experimental field}

The results of pre-planting initial soil analysis, soil physicochemical properties are presented in (Table 2). The electrical conductivity (EC) is a measure of salinity and ${ }_{\mathrm{p}} \mathrm{H}$ of the composite soil sample was analyzed using 1:1 soil water ratio of paste saturation method. Soil reaction (expressed as $\mathrm{pH}$ value) indicated the degree of soil acidity or alkalinity. It affects nutrient availability and toxicity, microbial activity and root growth. An activity such as decompositions of organic matter, applications of commercial fertilizers as well as farming practices affects the degree of soil reactions.

Table 2 Soil physico-chemical properties of the experimental field based on pre-planting soil sample $(0-15 \mathrm{~cm}$ depth) analysis

\begin{tabular}{|c|c|c|c|c|c|c|}
\hline \multirow[t]{2}{*}{ S.S $(0-15 \mathrm{~cm})$ depth } & \multirow{2}{*}{$\begin{array}{l}E C(\mathrm{ds} / \mathrm{cm}) \\
\mathrm{I:0I}\end{array}$} & \multirow{2}{*}{$\begin{array}{l}\mathrm{PH}(\mathrm{H} 2 \mathrm{O}) \\
\mathrm{I}: 0 \mathrm{I}\end{array}$} & \multirow[t]{2}{*}{$\% O C$} & \multirow[t]{2}{*}{$\% O M$} & \multirow[t]{2}{*}{$\% \mathbf{T N}$} & \multirow[t]{2}{*}{ Ava. P (ppm) } \\
\hline & & & & & & \\
\hline Block - I & 0.181 & 6.83 & I.5 | & 2.61 & 0.13 & 7.212 \\
\hline Block -2 & 0.226 & 6.37 & 1.39 & 2.4 & 0.12 & 7.205 \\
\hline Block-3 & 0.215 & 6.31 & I.4I & 2.43 & 0.122 & 6.928 \\
\hline Mean \pm SE & $0.207 \pm 0.170$ & $6.50 \pm 0.093$ & $1.44 \pm 0.037$ & $2.48 \pm 0.066$ & $0.124 \pm 0.003$ & $7.12 \pm 0.094$ \\
\hline
\end{tabular}

EC, electrical conductivity; $\mathrm{pH}$, power of hydrogen ion; OC-, organic carbon; Om, organic matter; TN, total nitrogen;Ava. P, available phosphorus; S. S, soil sample; $\mathrm{SE}$, standard errors of means.

As reported by Tilahun ${ }^{22}$ from the study of Forth and Ellis, (1997), which is in line with our present result that the average $\mathrm{pH}$ value of 6.50 (Table 2) indicated that the experimental soil type is classified as slightly acidic soil. Next to N, P is the most common plant growthlimiting nutrient in the tropical soils. ${ }^{23}$ The result analysis of available $\mathrm{P}$ was recorded in low ranges which were below the threshold levels (10 ppm) of $\mathrm{P}$ in the tropical soils. ${ }^{24}$ As cited by Mirutse..$^{25}$ for soil $\mathrm{N}$ and organic carbon, respectively, the total percentage of $\mathrm{N}$ is $0.124 \%$ and the response of tef to a different source of applied $\mathrm{N}$ indicated that the available form of the total soil $\mathrm{N}$ could be inadequate and it is likely to be stored in organic matter and clay minerals. The total mean percentage of organic carbon $(1.41 \%)$ content of the experimental site was comparable to soils in the semiarid regions. Due to the lower amount of organic materials applied to the soil and the complete removal of the biomass from the field, most cultivated soils of Ethiopia are poor in organic matter. ${ }^{26}$

\section{Effects of nitrogen fertilizer rates on phenological and growth parameters of Tef varieties days to heading}

Days to heading was significantly $(\mathrm{P}<0.05)$ affected by tef varieties and $\mathrm{N}$ fertilizer rate as well as by the interaction of the two effects. Generally, as $\mathrm{N}$ rate application increased, the number of days to heading was shortened. The longest days to a heading of Kora tef variety was recorded at $0,30,90$ and $120 \mathrm{~kg} \mathrm{~N} \mathrm{ha}^{-1}$, But a slightly lower day to heading was recorded at $60 \mathrm{~kg} \mathrm{~N} \mathrm{ha}^{-1}$. Based on this 
result, for Kora tef variety the optimum $\mathrm{N}$ fertilizer rate could be $60 \mathrm{~kg}$ $\mathrm{N} \mathrm{ha}^{-1}$, for a better flowering day. Both Boset and Asgori tef varieties have almost the same effects, except Asgori tef variety at the $0 \mathrm{~N}$ rate (control plot) had maximum days to heading (Table 3). This may be due to the reason that nitrogen fixation may exist and its availability may be deficient in the soil. This report was in agreement with the findings of $\mathrm{Assefa}^{27}$ that as the rate of NP increased the number of days to heading was condensed. From the three tef varieties, Boset and Asgori were early to flowering as compared to Kora. The present results were contradicted with the findings of Mebratu ${ }^{28}$ showing; that days to flowering of tef was delayed with the applications of inorganic fertilizer and farmyard manure and also with that of Gebretsadik, ${ }^{29}$ who reported that panicle emergence of tef was delayed with the applications of $\mathrm{N}$ fertilizer rates.

\section{Days to maturity}

Days to maturity of the tef plant were highly significantly $(\mathrm{P}<0.01)$ affected by tef varieties and $(\mathrm{P}<0.05)$ by $\mathrm{N}$ fertilizers. On the other hand, days to maturity was not significantly affected by the interaction of two effects (Table 3). The less of response to the $\mathrm{N}$ rate applications may be attributed to the variability of fertility levels or soil $\mathrm{N}$ content, and highly genetically difference between the three tef varieties. Studied reported that Asgori (DZ-01-99) tef variety was early released, and its days to maturity were 80-130 and this report was in agreement with our present findings (105.4).$^{30}$ The early flowering tef varieties of Boset and Asgori have respectively taken 101.4 and 103.79 days to mature, but as compared with the report of Mebratu, ${ }^{28}$ for Boset tef variety (using inorganic fertilizer) was lowered by five days. This contradicted our present findings, while it was comparable with the late maturing variety of Kora (108.9 days). Maturing groups of tef variety were due to genetic character and it may not much alter by growing environment. Average means of $\mathrm{N}$ rates (overall tef varieties), the days to maturity were almost similar effects except with 0,90 and $120 \mathrm{~kg} \mathrm{~N} \mathrm{ha}^{-1}$ rates that showed the maximum days to maturity.

\section{Plant height}

The analysis of variance showed that plant height was highly significant $(\mathrm{P}<0.01)$ affected by both varieties and $\mathrm{N}$ fertilizer application rates. The tef plants grown on the plots that received $\mathrm{N}$ fertilizer were significantly taller than as compared with these plants which are grown on the control plot (without $\mathrm{N}$ fertilizers) (Table 3). From the rating means of tef varieties (overall $\mathrm{N}$ rates), Kora (135.9) variety had the highest plant height followed by Boset (115.1), while the shortest plant height was for Asgori (111.7). From the grand means of $\mathrm{N}$ rates (overall of tef varieties), plant height increased consistently with increasing the levels of $\mathrm{N}$ such that the maximum plant height $(128.4 \mathrm{~cm})$ was obtained from the maximum $\mathrm{N}$ level $(120 \mathrm{~kg} / \mathrm{ha})$, while the lowest plant height $(112.8 \mathrm{~cm})$ was obtained from the control plot. Similarly, Tesfaye ${ }^{31}$ reported that plant height increased with $\mathrm{N}$ rates. Generally, the plant height of tef increased with $\mathrm{N}$ rate application rates and this was in line with the report of ${ }^{25}$ showing that the plant height of tef was linearly increased with $\mathrm{N}$ rate. On the other hand, as reported by Assefa, ${ }^{30}$ Asgori tef variety which was described with plant height $(53-100 \mathrm{~cm})$ had a mean plant height of $111.1 \mathrm{~cm}$ not in line with the present study.

Table 3 Phenological parameters as influenced by tef varieties and $\mathrm{N}$ rates

\begin{tabular}{|c|c|c|c|c|c|c|c|}
\hline \multicolumn{2}{|c|}{ Treatments } & \multicolumn{6}{|c|}{ Parameters } \\
\hline Varieties & $\begin{array}{l}\text { N rate } \\
\text { (kg/ha) }\end{array}$ & $\begin{array}{l}\text { Days to } \\
\text { heading }\end{array}$ & $\begin{array}{l}\text { Days to } \\
\text { maturity }\end{array}$ & $\begin{array}{l}\text { Plant } \\
\text { height } \\
(\mathrm{cm})\end{array}$ & $\begin{array}{l}\text { Panicle } \\
\text { length }(\mathrm{cm})\end{array}$ & $\begin{array}{l}\text { Total tiler } \\
\text { number }\end{array}$ & $\begin{array}{l}\text { Productive tiller } \\
\text { number }\end{array}$ \\
\hline \multirow{5}{*}{ Kora } & 0 & $50.67^{a}$ & $109.00^{\mathrm{a}}$ & $127.93^{\mathrm{a}}$ & $49.93^{\mathrm{a}}$ & $7.0^{\mathrm{a}}$ & $5.7^{\mathrm{a}}$ \\
\hline & 30 & $50.33^{\mathrm{ab}}$ & $107.67^{a}$ & $133.87^{a}$ & $50.20^{a}$ & $7.0^{\mathrm{a}}$ & $5.7^{\mathrm{a}}$ \\
\hline & 60 & $48.33^{b c}$ & $108.33^{\mathrm{a}}$ & $136.8^{a}$ & $50.87^{a}$ & $7.9^{\mathrm{a}}$ & $6.0^{\mathrm{a}}$ \\
\hline & 90 & $50.67^{a}$ & $109.33^{\mathrm{a}}$ & $139.67^{a}$ & $50.43^{\mathrm{a}}$ & $8.3^{\mathrm{a}}$ & $6.7^{\mathrm{a}}$ \\
\hline & 120 & $50.00^{\mathrm{ab}}$ & $110.33^{a}$ & $|4| .43^{a}$ & $51.70^{\mathrm{a}}$ & $8.0^{\mathrm{a}}$ & $6.0^{\mathrm{a}}$ \\
\hline \multirow{5}{*}{ Boset } & 0 & $46.33^{d}$ & $105.00^{\mathrm{a}}$ & $107.37^{\mathrm{a}}$ & $42.53^{\mathrm{a}}$ & $8.7^{\mathrm{a}}$ & $7.7^{\mathrm{a}}$ \\
\hline & 30 & $45.00^{d}$ & $102.00^{a}$ & $108.37^{a}$ & $42.10^{\mathrm{a}}$ & $8.7^{\mathrm{a}}$ & $7.0^{\mathrm{a}}$ \\
\hline & 60 & $45.00^{\mathrm{d}}$ & $100.67^{a}$ & $115.37^{\mathrm{a}}$ & $43.23^{\mathrm{a}}$ & $8.7^{\mathrm{a}}$ & $6.7^{\mathrm{a}}$ \\
\hline & 90 & $45.00^{d}$ & $105.67^{a}$ & $119.4^{a}$ & $42.20^{\mathrm{a}}$ & $8.7^{\mathrm{a}}$ & $7.0^{\mathrm{a}}$ \\
\hline & 120 & $45.00^{d}$ & $108.00^{\mathrm{a}}$ & $125.13^{\mathrm{a}}$ & $42.37^{a}$ & $8.3^{\mathrm{a}}$ & $7.3^{\mathrm{a}}$ \\
\hline \multirow{5}{*}{ Asgori } & 0 & $49.00^{\mathrm{bc}}$ & $104.00^{\mathrm{a}}$ & $103.07^{a}$ & $45.20^{\mathrm{a}}$ & $9.9^{\mathrm{a}}$ & $7.0^{\mathrm{a}}$ \\
\hline & 30 & $45.00^{d}$ & $104.33^{\mathrm{a}}$ & $107.90^{\mathrm{a}}$ & $46.03^{\mathrm{a}}$ & $10.3^{a}$ & $9.0^{\mathrm{a}}$ \\
\hline & 60 & $45.00^{d}$ & $104.00^{a}$ & $112.60^{\mathrm{a}}$ & $46.7^{\mathrm{a}}$ & $10.7^{a}$ & $8.7^{a}$ \\
\hline & 90 & $45.00^{d}$ & $107.00^{\mathrm{a}}$ & $116.23^{\mathrm{a}}$ & $46.17^{a}$ & $10.3^{a}$ & $8.3^{\mathrm{a}}$ \\
\hline & 120 & $45.00^{d}$ & $107.00^{\mathrm{a}}$ & $118.53^{\mathrm{a}}$ & $46.40^{\mathrm{a}}$ & $10.3^{a}$ & $8.7^{\mathrm{a}}$ \\
\hline S. E \pm & & 0.56 & 1.686 & 1.703 & 0.3362 & 0.75 & 0.93 \\
\hline \multicolumn{8}{|c|}{ Means of varieties (overall $\mathbf{N}$ rates) } \\
\hline Kora & & $50.00^{\mathrm{a}}$ & $108.9^{a}$ & $135.9^{\mathrm{a}}$ & $50.63^{a}$ & $7.53^{c}$ & $6.00^{c}$ \\
\hline Boset & & $45.27^{b}$ & $104.3^{b}$ & $115 . I^{b}$ & $42.49^{c}$ & $8.60^{b}$ & $7.13^{b}$ \\
\hline Asgori & & $45.8^{\mathrm{b}}$ & $105.4^{b}$ & $111.7^{c}$ & $45.9^{b}$ & $10.13^{\mathrm{a}}$ & $8.33^{\mathrm{a}}$ \\
\hline S. E \pm & & 0.251 & 0.754 & 0.762 & $0.94 I$ & 0.34 & 0.32 \\
\hline
\end{tabular}


Table continue

\begin{tabular}{|c|c|c|c|c|c|c|c|}
\hline \multicolumn{2}{|c|}{ Treatments } & \multicolumn{6}{|c|}{ Parameters } \\
\hline Varieties & $\begin{array}{l}N \text { rate } \\
(\mathrm{kg} / \mathrm{ha})\end{array}$ & $\begin{array}{l}\text { Days to } \\
\text { heading }\end{array}$ & $\begin{array}{l}\text { Days to } \\
\text { maturity }\end{array}$ & $\begin{array}{l}\text { Plant } \\
\text { height } \\
\text { (cm) }\end{array}$ & $\begin{array}{l}\text { Panicle } \\
\text { length }(\mathrm{cm})\end{array}$ & $\begin{array}{l}\text { Total tiler } \\
\text { number }\end{array}$ & $\begin{array}{l}\text { Productive tiller } \\
\text { number }\end{array}$ \\
\hline \multicolumn{8}{|c|}{ Means of $\mathbf{N}$ rate (overall tef varieties) } \\
\hline 0 & & $48.67^{a}$ & $106.0^{\mathrm{abc}}$ & $112.8^{\mathrm{e}}$ & $45.89^{b}$ & $8.2^{\mathrm{a}}$ & $6.8^{\mathrm{a}}$ \\
\hline 30 & & $46.78^{b}$ & $104.7^{\mathrm{ab}}$ & $116.6^{\mathrm{d}}$ & $46.11^{b}$ & $8.7^{\mathrm{a}}$ & $7.2^{\mathrm{a}}$ \\
\hline 60 & & $46.11^{\mathrm{b}}$ & $104.3^{\mathrm{c}}$ & $121.6^{\mathrm{c}}$ & $46.72^{\mathrm{a}}$ & $8.9^{\mathrm{a}}$ & 7. $1^{\mathrm{a}}$ \\
\hline 90 & & $46.89^{b}$ & $107.3^{\mathrm{ab}}$ & $125.1^{b}$ & $46.27^{\mathrm{ab}}$ & $9.1^{a}$ & $7.3^{\mathrm{a}}$ \\
\hline 120 & & $46.67^{b}$ & $108.7^{\mathrm{a}}$ & $128.4^{\mathrm{a}}$ & $46.82^{\mathrm{a}}$ & $8.9^{a}$ & $7.3^{\mathrm{a}}$ \\
\hline S.E \pm & & 0.323 & 0.973 & 0.98 & 0.1504 & 0.44 & 0.41 \\
\hline \multicolumn{2}{|c|}{ Over all mean } & 47.02 & 106.2 & 120.9 & 46.36 & 8.8 & 7.2 \\
\hline \multicolumn{2}{|l|}{ CV (\%) } & 2.1 & 2.7 & 2.4 & 1.3 & 14.9 & 17.3 \\
\hline
\end{tabular}

Values are the means of triplicate experiments and reported as mean \pm S.E. CV $=$ coefficient of variation and S.E $=$ standards errors of means. Means in the same column and within the same treatment category followed by different letters are significantly different as judged by LSD at $P \leq 0.05$.

\section{Panicle length}

The analysis of variance showed that panicle length was highly significantly $(\mathrm{P}<0.01)$ affected by varieties and $\mathrm{N}$ fertilizer rates, but not by the interaction effects. Of the three tef varieties, the highest $(56.07 \mathrm{~cm})$ and lowest panicle length $(42.49 \mathrm{~cm})$ of tef was observed for Kora and Boset, respectively (Table 3). From the observations of the average means of tef varieties, the panicle length of tef varieties was different and this mainly due to genetic difference among varieties.

On the other hand, regardless of tef varieties, the highest panicle length was recorded from the $\mathrm{N}$ rates of 60,90 and $120 \mathrm{~kg} \mathrm{~N} \mathrm{ha}^{-1}$ and the lowest panicle length of tef was recorded with the control plot and $30 \mathrm{~kg} \mathrm{~N} \mathrm{ha}^{-1}$, respectively (Table 3 ). The present findings did not agree with the reports of Mirutse ${ }^{25}$ showing; that panicle length of tef increased with higher rates of $\mathrm{N}$ applications. Thus, the present findings contradict the concepts that high $\mathrm{N}$ fertilizer promotes plant vegetative growth eventually leading to increased panicle length of plants. In contrast to the present results panicle length of tef increased with supplied inorganic and farmyard manures. ${ }^{28}$ In line with the other parameters, there were no significant differences in panicle length due to the application of $30 \mathrm{~kg} \mathrm{~N} \mathrm{ha}^{-1}$ and control plots. The panicle length of these tef varieties was no significantly different among 60, 90 and $120 \mathrm{~kg} \mathrm{~N} \mathrm{ha}^{-1}$ fertilizers and this may be due to the variability of soil fertility of the experimental site. Depending on this and from the economic points of view the optimum $\mathrm{N}$ source for tef varieties could be $60 \mathrm{~kg} \mathrm{~N}^{-1}$.

\section{Total and productive tiller numbers of tef varieties}

The total and number of productive tillers were not significantly affected by either the main effects $\mathrm{N}$ fertilizer rates or the interaction effects, but both of them were highly significantly affected by tef varieties $(\mathrm{P}<0.01)$. The highest means of the total $(10.13)$ and productive (8.3) tiller numbers were recorded from Asgori tef variety. But the lowest means of total (7.5) tiller and productive (6.00) tiller number were observed for Kora tef variety (Table 3 ).

Generally, there were no differences in the number of productive tillers among the levels of $\mathrm{N}$ fertilizers (overall tef varieties). This result is in agreement with the findings of Tesfaye ${ }^{31}$ who reported no significant differences in productive tillers between the higher $\mathrm{N}$ rate and the control plots. In contrast with the result of this study, Assefa ${ }^{32}$ reported that the number of productive tillers of tef was significantly increased with increasing rates of NPK. Giday ${ }^{10}$ also reported a positive and significant increase in the number of productive tillers with increasing rates of $\mathrm{N}$ fertilizer on tef.

\section{Effects of $\mathbf{N}$ Fertilizer Levels on Yield and Yield Component Parameters of Tef Varieties Lodging index}

The analysis of variance indicated that Lodging index was significantly $(\mathrm{P}<0.05)$ affected by $\mathrm{N}$ rates and the interaction of varieties, but not by tef varieties (Table 4 ). The interaction effects and grand means of $\mathrm{N}$ rates (overall tef varieties) indicated that lodging index was linearly increased with $\mathrm{N}$ rates. Thus, this was in line with the report of $\mathrm{Assefa}^{27}$ showing, that lodging index increased with the applications of NP fertilizer rates. Likewise, lodging index was reported to be highly significantly affected by the applications of more nutrients in the soil. ${ }^{33}$ Gebretsadik ${ }^{29}$ reported that lodging index increased with $\mathrm{N}$ fertilizer and this was in line with our present studies.

\section{Above - ground dry biomass yield}

Total above- ground dry biomass was highly significantly $(\mathrm{P}<0.01)$ affected by varieties, $\mathrm{N}$ rates as well as interactions of tef varieties and $\mathrm{N}$ rates. The highest $(8693,9120$ and 8387$)$ and the lowest $(6893,4520$ and $4853 \mathrm{~kg} \mathrm{ha}^{-1}$ ) of means of above ground dry biomass yield were obtained from Kora, Boset and Asgori tef varieties respectively (Table 4). For Boset and Asgori tef varieties, their maximum biomasses yield was recorded at $120 \mathrm{~kg} \mathrm{ha}^{-1}$. The mean values of $\mathrm{N}$ rates (overall tef varieties) indicated that above - ground biomass yield increased linearly with $\mathrm{N}$ rate except at $90 \mathrm{~kg} \mathrm{ha}^{-1}$, which had little more grain yield (Figure 1). This makes a case to have lower biomass yield. Generally, our present findings are in line with the results of Giday, ${ }^{10}$ showing that, and total above - ground biomass yield increased with $\mathrm{N}$ rate.

\section{Grain yield}

Applications of different $\mathrm{N}$ fertilizer rates were highly significantly $(p<0.01)$ increased the grain yield of tef varieties (Table 4). For Kora, Boset and Asgori tef varieties, the highest grain yield was recorded at 60 to $90 \mathrm{~kg} \mathrm{~N} \mathrm{ha}^{-1}$ of $\mathrm{N}$ fertilizer rates. Based on this trend and the economic point of view, it would be more profitable to use $60 \mathrm{~kg} \mathrm{~N} \mathrm{ha}^{-1}$ $\mathrm{N}$ rates instead of, 90 and $120 \mathrm{~kg} \mathrm{~N} \mathrm{ha}^{-1}$ (Figure 2). The low average means grain yield of $\left(1709,1402\right.$ and $1413 \mathrm{~kg} \mathrm{ha}^{-1}$ for Kora, Boset and Asgori respectively) was obtained from the control plots. This may be the indicative of low availability of soil $\mathrm{N}$ at the experimental site. This was also positively correlated with the means of $\mathrm{N}$ rates (overall 
tef varieties) showed that grain yield increase with $\mathrm{N}$ rate applications. Among these three tef varieties Boset was the first yielder (Table 4). Thus, our present finding was in agreement with the report of Fano. ${ }^{34}$

\section{Straw yield}

The analysis of variance showed that the two main factors (varieties and $\mathrm{N}$ rates) and their interactions were highly significant $(\mathrm{P}<0.01)$ affected for straw yields. The lowest mean straw yield of (5184, 3118 and $\left.3441 \mathrm{~kg} \mathrm{ha}^{-1}\right)$ was obtained from the control plot of Kora, Boset and Asgori respectively (Table 4). The highest mean yields of 6857,7119 and $7119 \mathrm{~kg} \mathrm{ha}^{-1}$ ) for Kora, Boset and Asgori tef varieties respectively were obtained from the application of 60 and $120 \mathrm{~kg} \mathrm{~N} \mathrm{ha}^{-1}$. Boset and Asgori tef varieties showed lowest grain yield with $\mathrm{N}$ rate of $120 \mathrm{~kg} \mathrm{~N} \mathrm{ha}^{-1}$. That is why their maximum straw yields become higher at this rate. But for kora tef variety its straw yield was optimum at $60 \mathrm{~kg} \mathrm{~N} \mathrm{ha}^{-1}$, whereas its grain was almost equal with the rate of $90 \mathrm{~kg} \mathrm{ha}^{-1}$. Generally, from the means of individual $\mathrm{N}$ rate (overall tef varieties) total straw yield increased with increasing $\mathrm{N}$ fertilizer rates (Table 4). In line with the present findings, Giday ${ }^{10}$ also reported that straw yield increased with $\mathrm{N}$ rate on tef. Likewise, the current results also confirmed the findings of Gebretsadik; ${ }^{28}$ that grain yield increased with $\mathrm{N}$ fertilizer rates.

Table 4 Yield and yield parameters of tef as influenced by varieties and nitrogen fertilizer rates

\begin{tabular}{|c|c|c|c|c|c|c|c|}
\hline \multicolumn{2}{|c|}{ Treatments } & \multicolumn{6}{|c|}{ Parameters } \\
\hline Varieties & $\begin{array}{l}\text { N rate } \\
\text { (kg/ha) }\end{array}$ & $\begin{array}{l}\text { Lodging } \\
\text { Index (\%) }\end{array}$ & $\begin{array}{l}\text { Above ground } \\
\text { dry biomass } \\
\text { (kg/ha) }\end{array}$ & $\begin{array}{l}\text { Grain yield } \\
\text { (kg/ha) }\end{array}$ & $\begin{array}{l}\text { Straw yield(kg/ } \\
\text { ha) }\end{array}$ & $\begin{array}{l}\text { Harvest } \\
\text { index (\%) }\end{array}$ & $\begin{array}{l}1000 \text { seed } \\
\text { weight }(\mathrm{g})\end{array}$ \\
\hline \multirow{5}{*}{ Kora } & 0 & $55.67^{\text {def }}$ & $6893^{f}$ & $1709^{e}$ & $5184^{f g}$ & $0.2483^{\text {def }}$ & $0.290^{\mathrm{a}}$ \\
\hline & 30 & $58.05^{\text {cde }}$ & $7120^{\text {ef }}$ & $1775^{\text {de }}$ & $5345^{f}$ & $0.2496^{\text {def }}$ & $0.293^{\mathrm{a}}$ \\
\hline & 60 & $58.05^{\text {cde }}$ & $8693^{\mathrm{ab}}$ & $1836^{\mathrm{cd}}$ & $6857^{\mathrm{ab}}$ & $0.2113^{h}$ & $0.307^{\mathrm{a}}$ \\
\hline & 90 & $65.53^{\mathrm{ab}}$ & $8080^{\mathrm{cd}}$ & $1926^{b c}$ & $6154^{\mathrm{cd}}$ & $0.2384^{f g}$ & $0.310^{\mathrm{a}}$ \\
\hline & 120 & $67.87^{a}$ & $8213^{b c}$ & $1754^{\mathrm{de}}$ & $6459^{\mathrm{bc}}$ & $0.2143^{h}$ & $0.283^{a}$ \\
\hline \multirow{5}{*}{ Boset } & 0 & $54.33^{\mathrm{ef}}$ & $4520^{\mathrm{g}}$ & $1402^{f}$ & $6000^{\mathrm{a}}$ & $0.3108^{\mathrm{a}}$ & $0.310^{\mathrm{a}}$ \\
\hline & 30 & $57.00^{\text {de }}$ & $6613^{f}$ & $1859^{\mathrm{cd}}$ & $3118^{h}$ & $0.2817^{\mathrm{bc}}$ & $0.263^{\mathrm{a}}$ \\
\hline & 60 & $60.22^{\text {bcde }}$ & $8013^{\text {cd }}$ & $2115^{a}$ & $4754^{g}$ & $0.2637^{\text {cde }}$ & $0.287^{a}$ \\
\hline & 90 & $60.40^{\text {bcde }}$ & $7613^{\text {de }}$ & $2035^{\mathrm{ab}}$ & 5899 de & $0.2680^{\mathrm{cd}}$ & $0.293^{\mathrm{a}}$ \\
\hline & 120 & $62.63^{\mathrm{ab}}$ & $9120^{a}$ & $200 I^{b}$ & $5578^{\text {ef }}$ & $0.2193^{g h}$ & $0.290^{\mathrm{a}}$ \\
\hline \multirow{5}{*}{ Asgori } & 0 & $48.33^{f}$ & $4853^{g}$ & $1413^{f}$ & $7119^{a}$ & $0.2913^{\mathrm{ab}}$ & $0.317^{a}$ \\
\hline & 30 & $60.00^{\mathrm{abcd}}$ & $6893^{f}$ & $|49|^{f}$ & $344 I^{h}$ & $0.2170^{\mathrm{h}}$ & $0.323^{a}$ \\
\hline & 60 & $61.00^{\mathrm{abc}}$ & $7947^{\mathrm{cd}}$ & $1762^{\mathrm{de}}$ & $5402^{\text {ef }}$ & $0.2220^{\text {ef }}$ & $0.360^{\mathrm{a}}$ \\
\hline & 90 & $61.81^{a b c}$ & $7587^{\mathrm{de}}$ & $1865^{\mathrm{cd}}$ & $6184^{\mathrm{cd}}$ & $0.2460^{\mathrm{ef}}$ & $0.347^{a}$ \\
\hline & 120 & $62.04^{\mathrm{ab}}$ & $8387^{b c}$ & $1268^{8}$ & $5722 d^{\text {ef }}$ & $0.1517^{i}$ & $0.347^{a}$ \\
\hline S.E \pm & & 2.532 & 190.7 & 39 & $|87.1|$ & 0.0073 & 0.019 \\
\hline \multicolumn{8}{|c|}{ Means of varieties (overall $\mathbf{N}$ rates) } \\
\hline Kora & & $61.03^{\mathrm{a}}$ & $7800^{\mathrm{a}}$ & $1800^{a}$ & $6000^{\mathrm{a}}$ & $0.2324^{b}$ & $0.297^{b}$ \\
\hline Boset & & $59.93^{\mathrm{a}}$ & $7176^{b}$ & $1883^{a}$ & $5293^{c}$ & $0.2687^{\mathrm{a}}$ & $0.289^{b}$ \\
\hline Asgori & & $60.44^{a}$ & $7133^{b}$ & $1560^{c}$ & $5574^{b}$ & $0.2256^{\mathrm{b}}$ & $0.339^{\mathrm{a}}$ \\
\hline S.E \pm & & 1.132 & 85.3 & 17.4 & 83.68 & 0.0033 & 0.009 \\
\hline \multicolumn{8}{|c|}{ Means of $\mathbf{N}$ rates (overall tef varieties) } \\
\hline 0 & & $52.78^{c}$ & $5422^{\mathrm{e}}$ & $1508^{c}$ & $3914^{e}$ & $0.2834^{\mathrm{a}}$ & $0.306^{\mathrm{a}}$ \\
\hline 30 & & $59.02^{\mathrm{b}}$ & $6876^{d}$ & $1708^{b}$ & $5167^{d}$ & $0.2494^{b}$ & $0.293^{\mathrm{a}}$ \\
\hline 60 & & $63.76^{\mathrm{a}}$ & $8218^{b}$ & $1904^{\mathrm{a}}$ & $6313^{b}$ & $0.2323^{c}$ & $0.318^{\mathrm{a}}$ \\
\hline 90 & & $62.61^{\mathrm{ab}}$ & $7760^{c}$ & $1942^{\mathrm{a}}$ & $5818^{c}$ & $0.2508^{b}$ & $0.317^{\mathrm{a}}$ \\
\hline 120 & & $64.18^{\mathrm{a}}$ & $8573^{a}$ & $1674^{b}$ & $6899^{d}$ & $0.195 \mathrm{I}^{\mathrm{d}}$ & $0.307^{a}$ \\
\hline S.E \pm & & 1.462 & 190.7 & 39 & 108.03 & 0.0042 & 0.011 \\
\hline Over all me & & 60.47 & 7369.67 & 1747.67 & 5622 & 0.22422 & 0.308 \\
\hline CV (\%) & & 7.3 & 4.5 & 3.9 & 5.8 & 5.2 & 10.8 \\
\hline
\end{tabular}

Values are the means of triplicate experiments and reported as mean \pm S.E. CV $(\%)=$ Coefficient of variation, S.E $=$ standards of errors of means, means in the same column and within the same treatment category followed by different letters are significantly different as judged by LSD at $\mathrm{p} \leq 0.05$. 


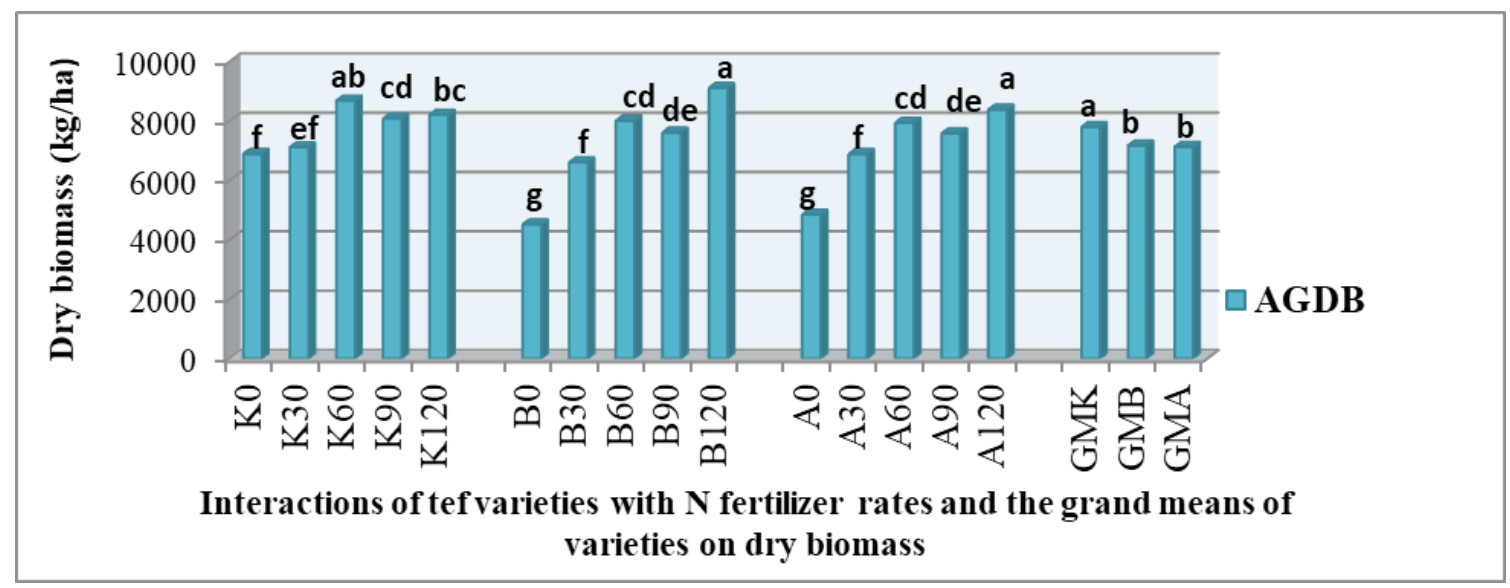

Figure I Interaction effects of tef varieties with $\mathrm{N}$ rates and the grand means of varieties on the above ground dry biomass $(A G D B), K=K o r a, B=B o s e t$ and $A$ =Asgori tef varieties, 0 to I 20 indicate five $\mathrm{N}$ rates kg ha- I, while G.MK, G.MB and G.MA = grand means of Kora, Boset and Asgori tef varieties.

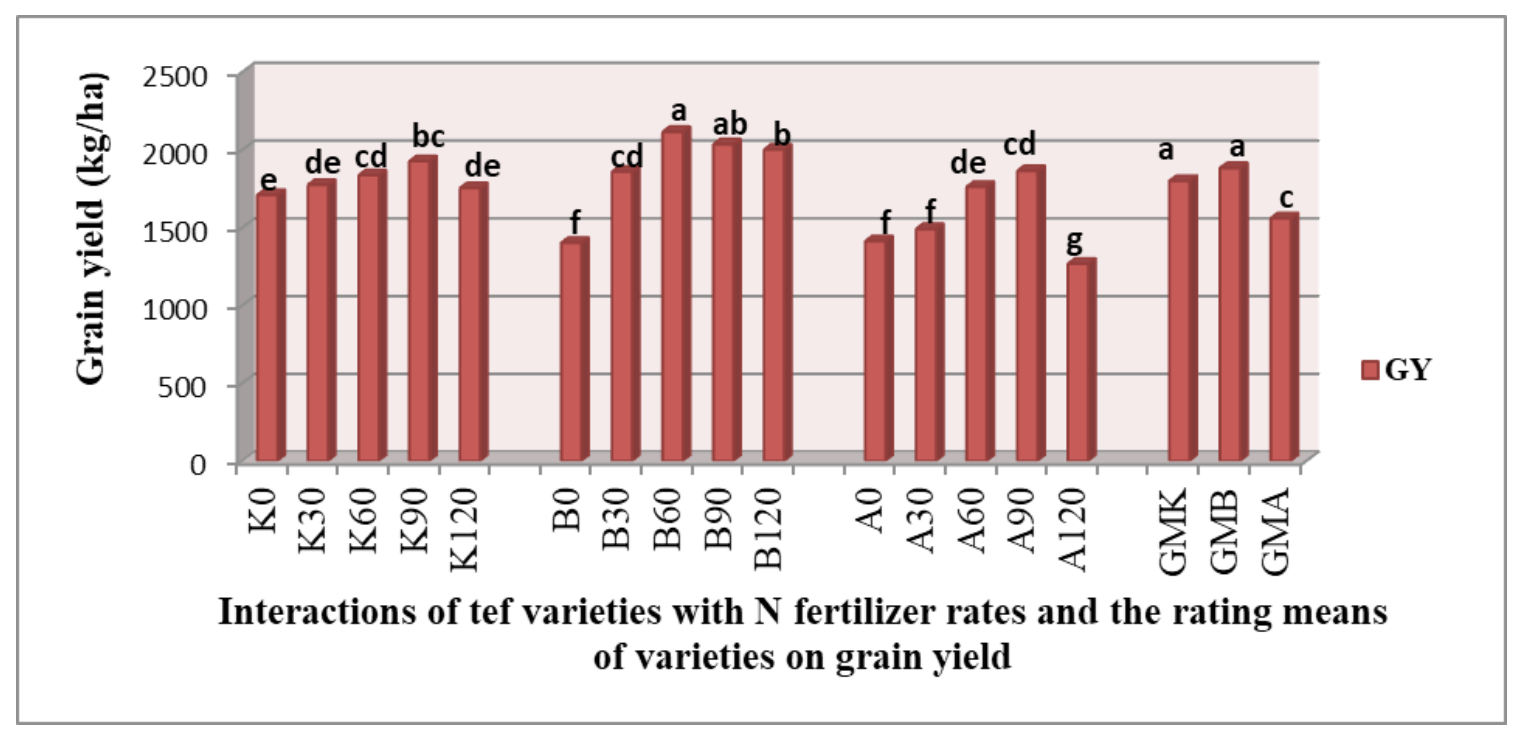

Figure 2 Interaction effects of tef varieties with $N$ rates and the grand means of varieties on the grain yield $(G Y), K=K o r a, B=B o s e t$ and $A=A s g o r i$ tef varieties, 0 to 120 indicate five $\mathrm{N}$ rates $\mathrm{kg}$ ha- I, while G.MK, G.MB and G.MA = grand means of Kora, Boset and Asgori tef varieties.

\section{Harvest index}

The effect of applications of different nitrogen fertilizer rates on the tef harvest index was highly significant $(p<0.01)$ affected. The harvest index of tef for all control plots was higher than from all plots having different nitrogen rates. This was due to higher shoot biomass coupled with lower grain yield obtained from the control plots (Table 4). This result contradicted with the findings of Giday ${ }^{10}$ showing; that HI was higher at all nitrogen rate applications except the control plots. For these three tef varieties, Kora, Boset and Asgori at which their harvest index was lowest at $120 \mathrm{~kg} \mathrm{ha}^{-1}$ this was due to higher above ground dry biomass of tef varieties (Figure 3 ). Averaged over all the three tef varieties, the means of $\mathrm{N}$ rates revealed the harvest index did not increase with $\mathrm{N}$ fertilizer rates (Figure 3 ). This was not confirmed with the findings of Habtamu ${ }^{35}$ showing; that higher harvest index values were obtained with maximum $\mathrm{N}$ rates.

\section{Thousand seed weight}

Thousand kernel weight was highly significantly $(\mathrm{P}<0.01)$ affected by varieties, but not by $\mathrm{N}$ fertilizer rates as well as the interactions of tef varieties and $\mathrm{N}$ rates (Table 4). The highest mean thousand kernel weight (0.3387) was noted for brown-seeded variety Asgori as compared to other varieties that showed comparable means (Table 4). The present findings with respect to $\mathrm{N}$ fertilizer rates are not in line with the results of Giday, ${ }^{10}$ who found that thousand seed weight increased with $\mathrm{N}$ rates. On the other hand, Alemu, ${ }^{28}$ that thousand seed weight increased with NP rate.

\section{Summary and conclusion}

Phenological and yield and yield components of tef varieties were significantly affected by the applications of $\mathrm{N}$ fertilizer rates and their interactions. The analysis of variance showed that plant height and panicle length were highly significantly $(\mathrm{P}<0.01)$ affected by both varieties and $\mathrm{N}$ fertilizer rates. Total and productive tiller number and days to maturity were only highly significantly $(\mathrm{P}<0.01)$ affected by tef varieties. And $\mathrm{N}$ fertilizer rates have significant effects on days to maturity. The interaction of $\mathrm{N}$ rates and tef varieties had significance effect on days to heading at $(\mathrm{P}<0.05)$. The tef plants grown on the plots that received $\mathrm{N}$ fertilizer rates were significantly taller than as 
compared plants grown on the control plot. From the average of tef varieties (overall $\mathrm{N}$ rates), Kora variety had the highest plant height followed by Boset, while the shortest plant height was observed from Asgori tef variety. Kora and Boset tef varieties had the highest and lowest panicle length, respectively. From the average means of tef varieties the panicle length of varieties was different and this mainly due to genetic difference among varieties. The number of days to heading was shortened as the rates of $\mathrm{N}$ application increased. Interactions of $\mathrm{N}$ rates with Boset and Asgori tef varieties had the same effects on the days to heading, except the control plot which had maximum days to heading. This may be due to the reason that nitrogen fixation may exist and its availability may be deficient in the soil.

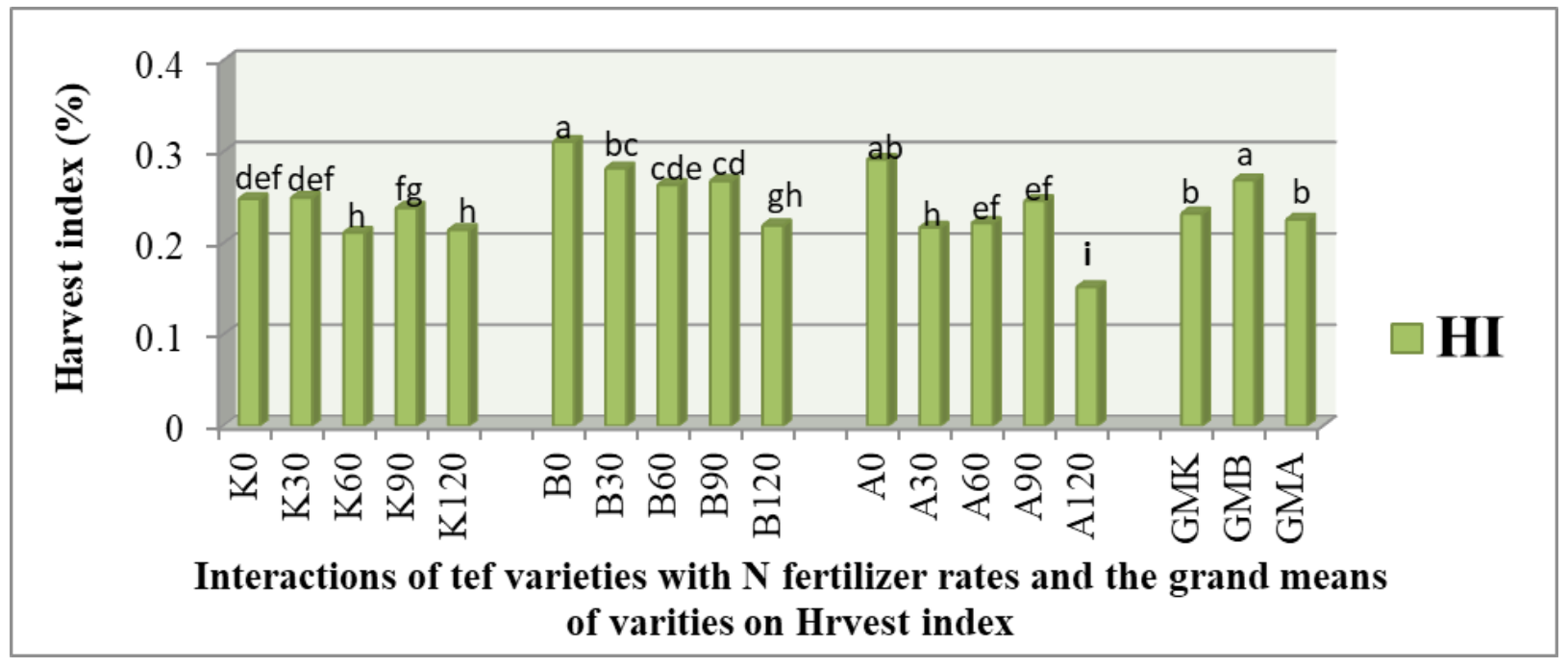

Figure 3 Interaction effects of tef varieties with $\mathrm{N}$ rates and the grand means of varieties on the harvest index $(\mathrm{HI}), \mathrm{K}=\mathrm{K}$ ora, $\mathrm{B}=\mathrm{B}$ oset and $\mathrm{A}=\mathrm{Asgori}$ tef varieties, 0 to 120 indicate five $\mathrm{N}$ rates $\mathrm{kg}$ ha- I, while G.MK, G.MB and G.MA = grand means of Kora, Boset and Asgori tef varieties.

The yield and yield components parameters such as grain yield, above ground dry biomass and straw yield were highly significantly $(\mathrm{P}<0.01)$ affected by the two main and their interactions effects. Lodging index was only significantly $(\mathrm{P}<0.05)$ affected by $\mathrm{N}$ fertilizer rates and it was increased linearly with $\mathrm{N}$ rates. Thousand kernel weight and harvest index were highly significantly $(\mathrm{P}<0.01)$ affected only by tef varieties and $\mathrm{N}$ rates, respectively. Biomass was increased with $\mathrm{N}$ rates. Grand means of $\mathrm{N}$ rates indicated that above ground dry biomass was linearly increased with $\mathrm{N}$ rates. A better grain yield was obtained $60-90 \mathrm{~kg} \mathrm{~N} \mathrm{ha}^{-1}$. And therefore, based on the economic point of view, it would be more profitable to use $60 \mathrm{~kg} \mathrm{~N} \mathrm{ha}^{-1} \mathrm{~N}$ rates. HI from the control plots was higher than from all plots having different nitrogen rates. This was due to higher shoot biomass coupled with lower grain yield obtained from the control plots. Averaged over all the three tef varieties, the means of $\mathrm{N}$ rates revealed $\mathrm{HI}$ did not increase with $\mathrm{N}$ fertilizer rates.

\section{Acknowledgments}

The Ethiopian Institute of Agricultural Research (EIAR) and Addis Ababa University (AAU) supported this research program. And I would like to acknowledge to Debre Zeit Agricultural Research Center (ZARC), tef research staff, for their valuable assistance during this research accomplishment.

\section{Funding}

None.

\section{Conflicts of interest}

The authors declare there are no conflicts of interest.

\section{References}

1. Seyfu Ketema. Tef (Eragrostistef): breeding, genetic resources, agronomy, utilization and role in ethiopian agriculture. Addis Ababa, Ethiopia: Institute of Agricultural Research; 1993.

2. Bekele E, Lester R. Biochemical assessment of the relationships of Eragrostis tef (Zucc.) Trotter with some wild Eragrostis species (Gramineae). Annals of Botany. 1981;48(5):717-725.

3. Akhtar T. The cytology of Eragrostis with special reference to E. tef and its relatives. University of London; 1986.

4. Yu Ju-K, Sun Q, Rota L, et al. Expressed sequence tag analysis in tef (Eragrostis tef (Zucc) Trotter). Genome. 2006;49(4):365-372.

5. Yu J-K, Graznak E, Breseghello F, et al. QT mapping of agronomic traits in tef [Eragrostis tef (Zucc) Trotter]. Biomed central plant biology. 2007;7(1):30.

6. Central Stastical agency (CSA). Agricultural sample survery report on area and production of belg season crops for private peasant holdings. 2008.

7. CSA (Central Statistical Agency). Agricultural sample survey 2010/2011. Reports on area under cultivation, yield and production of major crops for 2009/10-2010/11 main (Meher) season, Ethiopia. 2011.

8. Tefera $\mathrm{H}$. The genetics of quantitative traits in tef. In: HailuTefera, Getachew Belay and Mark Sorrels, editors. Narrowing the Rift: Tef Research and Development. Proceedings of the International Workshop on Tef Genetics and Improvement, 16-19 October 2000, Addis Ababa, Ethiopia; 2001:87-98

9. Balesh T, Bernt, A, Arvid B. Availability of organic nutrient sources and their effects on yield and nutrient recovery of tef [Eragrostis tef (Zucc.) Trotter] and on soil properties. Journal of Plant Nutrition and Soil Science. 2007;170:543-550. 
10. Giday O, Heluf G, Berhe T. Response of teff (Eragrostis tef) to different rates of slow release and conventional urea fertilizers in vertisols of Southern Tigray, Ethiopia. Advances in Plants \& Agriculture Research. 2014;1(5):1-8.

11. Bock B. Efficient use of nitrogen in cropping systems. Nitrogen in crop production. 1984:273-294.

12. Negassa W, Tolera A, Minale L, et al. Soil Fertility Management Technologies for Sustainable Maize Production in Ethiopia. In: Worku M, Twumasi-Afriyie S, Wolde L, editors. Meeting the challenges of global climate change and food security through innovative maize research. Proceedings of the Third National Maize Workshop of Ethiopia. Addis Ababa, Ethiopia. 2012:123-127.

13. Gelaw AM, Singh B, Lal R. Soil organic carbon and total nitrogen stocks under different land uses in a semi-arid watershed in Tigray, Northern Ethiopia. Agriculture, Ecosystems \& Environment. 2014;188:256-263.

14. Chivenge P, Vanlauwe B, Six J. Does the combined application of organic and mineral nutrient sources influence maize productivity? A meta-analysis. Plant and Soil. 2011;342:1-30.

15. Aldrich SR, Scott WO, Leng ER. Modern corn production. 1975.

16. Stoorvogel J, Smaling E. Assessment of soil nutrient depletion in SubSaharan Africa: Report. 1990;28:1983-2000.

17. Jenkinson D. Nitrogen in UK arable agriculture. Journal of the Royal Agricultural Society of England. 1986;147:178-189.

18. Walkley A, Black IA. An examination of the Degtjareff method for determining soil organic matter, and a proposed modification of the chromic acid titration method. Soil science. 1934;37(1):29-38.

19. Bremner J. Determination of nitrogen in soil by the Kjeldahl method. The Journal of Agricultural Science. 1960;55(1):11-33.

20. Olsen SR. Estimation of available phosphorus in soils by extraction with sodium bicarbonate. United States Department of Agriculture; Washington; 1954.

21. Caldicott JJ, Nuttall AM. A method for the assessment of lodging in cereal crops. Journal of the National Institute of Agricu ltural Botany. 1979.

22. Tilahun G. Soil fertility status as influenced by different land uses in maybar areas of south wello zone, north Ethiopia. haramaya university, un published document; 2007.

23. Abebe M. The challenges and future prospects of soil chemistry in Ethiopia. Food and Agricultural Organizations; 1996.

24. Sánchez PA, Couto W, Buol SW. The fertility capability soil classification system: interpretation, applicability and modification. Geoderma. 1982;27(4):283-309.
25. Mirutse F, Haile M, Kebede F, et al. Response of Teff [Eragrostis (teff) Trotter] to phosphorus and Nitrogen on Vertisol at North Ethiopia. Journal of the drylands. 2009;2(1):8-14.

26. Gebreselassie Y. Selected chemical and physical characteristics of soils of Adet research center and its testing sites in North-western Ethiopia. Ethiopian Journal of Natural Resources. 2002.

27. Assefa A, Tana T, Abdulahi J. Effects of compost and inorganic NP rates on growth, yield and yield components of tef (Eragrotis teff (Zucc.) Trotter) in Girar Jarso District, central highland of Ethiopia. Journal of Fertilizers \& Pesticides. 2016;7:174.

28. Mebratu Y, Raghavaiah CV, Ashagre H. Production potential of tef (Eragrostis tef (Zucc.) Trotter) genotypes in relation to integrated nutrient management on vertisols of mid high lands of Oromia region of Ethiopia. East Africa. Advances in Crop Science and Technology. 2016;4:249.

29. Gebretsadik KGAEH. Determination time of nitrogen fertilizer top dressing for teff grown on vertisols in the Northern part of Ethiopia. Journal of Natural Sciences Research. 2016.

30. Assefa K, Chanyalew S, Metaferia G. Conventional and molecular tef breeding. Tef Improvement. 2013. 33 p.

31. Tesfaye K, Tolosa S. Effects of inorganic fertilizer types and sowing methods of variable seed rates on yield and yield components of teff [Eragrostis tef (Zucc.) Trotter] in Ada'a woreda, central Ethiopia. Haramaya University; 2012.

32. Asefa F, Debela A, Mohammed M. Evaluation of teff [Eragrostistef (Zuccagni) Trotter] responses to different rates of NPK along with $\mathrm{Zn}$ and B in didessa district, Southwestern Ethiopia. World Applied Sciences Journal. 2014;32:2245-2249.

33. Tams AR, Mooney SJ, Berry PM. The effect of lodging in cereals on morphological properties of the root-soil complex. In super soil 2004 3rd Austlaria. New Zealan Soils Conferenc; 2004.

34. Dargo F, Miekbib F, Assefa K. Genetic gain in grain yield potential and associated traits of tef [Eragrostistef (Zucc.)Trotter] in Ethiopia. Global Journals Inc. (United States of America). 2016;16(6):1-17.

35. Gebretsadik H, Haile M, Yamoah CF. Tillage Frequency, soil compaction and $\mathrm{N}$-fertilizer rate effects on yield of teff (Eragrostis Tef (Zucc) Trotter) in central zone of Tigray, Northern Ethiopia. Momona Ethiopian Journal of Science. 2009;1(1):82-94. 